\title{
Penicillus capitatus: an algal island for macrocrustaceans
}

\author{
Allan W. Stoner \\ Center for Energy and Environment Research, University of Puerto Rico, College Station, Mayaguez, Puerto Rico 00708
}

\begin{abstract}
Abundance and species richness of crustaceans associated with the calcareous green alga Penicillus capitatus in Puerto Rico increased with algal size. Faunal abundance was higher in the dry season than in the wet season, but species-area regressions were identical for the 2 periods. Faunal abundance rather than algal size, however, proved to be the best predictor of crustacean species richness on $P$. capitatus. Although there were no negative associations among species pairs, qualitative and quantitative changes in the crustacean assemblages during recolonization of defaunated $P$. capitatus and increasing dominance with animal density suggest the potential significance of differential immigration rates, displacement of certain taxa, and positive associations in explaining variation in species composition and species richness. Higher abundances of crustaceans (particularly amphipods and tanaidaceans) were found on $P$. capitatus than in the surrounding seagrass (Halodule wrightii) habitat; this is probably a function of protection from fish predators and habitat selectivity.
\end{abstract}

\section{INTRODUCTION}

Island land masses have long been used to study colonization processes, coexistence of similar species, density dependent phenomena, and species-area effects. Recently, small habitat islands in marine habitats have been examined for some of the same reasons (Abele \& Patton 1976, Gotelli \& Abele 1982, Gunnill 1982a, Lewis 1982, Abele 1984, Stoner \& Greening 1984). The calcareous green alga Penicillus capitatus Lamarck, found in shallow subtidal waters throughout the Caribbean Sea, the Bahamas, Florida and Bermuda (Taylor 1960), provides a convenient model for testing hypotheses related to island biogeographic processes. The alga is composed of interwoven coenocytic filaments forming a rhizoidal base, a thin, rigid stripe, and a brush-like capitulum of free and dichotomously branched filaments (Friedman \& Roth 1977). The capitula of $P$. capitatus support large communities of macrofauna dominated numerically by small Crustacea, mostly amphipods, tanaidaceans and large harpacticoid copepods. Small (late juvenile) and large $P$. capitatus (to $15 \mathrm{~cm}$ tall) are identical in basic structure, except size, and represent an ideal model for examining species-area relations where habitat heterogeneity is constant. In this study, I examine numbers of individuals, numbers of species, and species composition of crustaceans with respect to $P$. capitatus size during the dry and wet seasons in Puerto Rico. Further, because interspecific interactions may influence the composition of a species assemblage, tests of interspecific association were employed and recolonizations of defaunated $P$. capitatus were examined.

\section{MATERIALS AND METHODS}

Site description. All collections and experiments were conducted near Punta Ostiones, 7 miles south of Mayaguez on the west coast of Puerto Rico $\left(18^{\circ} 05.5^{\prime} \mathrm{N}\right.$, $\left.67^{\circ} 12.0^{\prime} \mathrm{W}\right)$. The study site is a sublittoral band of coarse calcareous sand, averaging $80 \mathrm{~m}$ in width, protected by a fringing coral reef front. Water depths within the study area are less than $60 \mathrm{~cm}$ with a tidal range of ca $30 \mathrm{~cm}$. The shallow area is subject to relatively constant high salinities (>32\%). Temperatures during the collecting period ranged from 27 to $32^{\circ} \mathrm{C}$ with diurnal temperature excursions of as much as $4 \mathrm{C}^{\circ}$. The primary set of collections and recolonization experiment were made in a bed of the seagrass Halodule wrightii (40 to $170 \mathrm{~g}$ dry $\mathrm{wt} \mathrm{m}^{-2}$ ), where Penicillus capitatus is abundant (ca 25 to 30 ind. $\mathrm{m}^{-2}$ ). At this seagrass site, mean depth was $25 \mathrm{~cm}$ and wave energy was low, but sufficient to prevent accumulation of fine sediment. 'Reef collections' of $P$. capitatus were made in the coral rubble zone of the backreef where 
the alga is abundant in sandy patches 25 to $50 \mathrm{~cm}$ deep. Wave surge is greater in this area than in the $H$. wrightii area, and water temperatures show less diurnal fluctuation.

Collections. Individual Penicillus capitatus were covered, in situ, with $18 \mathrm{oz} .(510 \mathrm{ml})$ plastic bags, removing the rhizoid before sealing so that infauna were not included in the sample. Forty individual algae were collected in April 1984 (dry season) and 38 were collected in July 1984 (wet season), all of these from the seagrass area. Samples were collected nonrandomly in an attempt to include an even distribution of $P$. capitatus sizes from late juveniles through to the largest available. Fifteen $P$. capitatus were collected in a similar manner from the backreef area in July 1984.

Concurrent with Penicillus capitatus collections, epifauna of the seagrass area were sampled with a 15 by $15 \mathrm{~cm}$ steel box covered with $0.5 \mathrm{~mm}$ mesh. The seagrass cutter is equipped with a serrated steel blade designed to take macrophytes and $1 \mathrm{~cm}$ of sediment. Four replicates were collected in haphazard fashion (but avoiding $P$. capitatus) in the sparse stand of Halodule wrightii for comparison of the seagrass epifauna with that of $P$. capitatus. Seagrass samples were sieved in the field on a $0.50 \mathrm{~mm}$ screen. All samples, $P$. capitatus and $H$. wrightii, were preserved in a $10 \%$ formaldehyde solution. ( $P$. capitatus was rare in beds of other seagrass species; these beds were not sampled for this study.)

In the laboratory, individual Penicillus capitatus capitula and Halodula wrightii blades were vigorously rinsed with fresh water and the faunal associates were collected on a $0.50 \mathrm{~mm}$ mesh screen. The macrophytes were measured for dry weight after being held in an oven at $80^{\circ} \mathrm{C}$ until constant mass was observed. All crustaceans were sorted from remaining sediment and detritus by hand, using a dissecting microscope. All were identified to the lowest possible taxonomic unit and measured for total length. Other macrofauna, such as polychaetes and gastropods, made up less than $4 \%$ of the total fauna and are not considered here.

Recolonization experiment. In April, on the day following routine Penicillus capitatus collections, a field experiment was begun to examine patterns of colonization of the alga by motile Crustacea. In a large, uniform area of sparse Halodule wrightii, three 90 by $90 \mathrm{~cm}$ string quadrats were fixed to the bottom and all $P$. capitatus were removed. $P$. capitatus of the appropriate size for the experiment were gently pulled from the area in and around the quadrats, being careful to retain as much of the rhizoid as possible. The capitula were then washed in 3 changes of fresh water to remove the animals, and held in a tray of seawater until replanting. Preliminary experiments examining $P$. capitatus handled in this manner showed that the defaunation method was $100 \%$ effective in removing taxa retained on a $0.5 \mathrm{~mm}$ screen. The quadrats were then each planted with 20 defaunated $P$. capitatus of ca equal and average size $(0.29 \pm 0.10 \mathrm{~g}$ dry wt) on $15 \mathrm{~cm}$ centers. After placement in the quadrats, the capitula of the alga quickly accumulated a light dusting of silt, and the transplants appeared green and healthy until Day 6 of the recolonization when the experiment was terminated.

In a manner similar to that described for routine collections, 2 Penicillus capitatus were randomly removed from each grid on a schedule of: 1 h $20 \mathrm{~min}$, $3 \mathrm{~h}, 6 \mathrm{~h}, 10 \mathrm{~h}, 21 \mathrm{~h}, 2 \mathrm{~d}, 3 \mathrm{~d}, 4 \mathrm{~d}$ and $6 \mathrm{~d}$. (Time zero was at 0940 h.) Because some of the alga showed signs of deterioration, such as loss of filaments and color, on Day 6, this last collection was not included in the analysis. Collections were processed as previously described. During the experiment, water temperatures were recorded between 26.9 and $31^{\circ} \mathrm{C}$, and depth at the site ranged from 12 to $26 \mathrm{~cm}$.

\section{RESULTS}

\section{Collections}

The number of macrofaunal individuals found on Penicillus capitatus was significantly correlated with $P$. capitatus weight. $\log _{10}$-transformations provided normal distribution of residuals and highly significant correlation coefficients (Fig. 1, Table 1), not found for untransformed data. Analysis of covariance with weight as the covariate showed that linear regressions for the wet and dry seasons were not significantly different in slope, but July collections yielded signifi-

Table 1. Penicillus capitatus. Summary statistics for linear regressions of number of individuals and species richness of macrofauna found on capitula. $\mathrm{N}$ : number of individuals; $\mathrm{S}$ : number of species; W: P. capitatus dry weight

\begin{tabular}{|c|c|c|c|c|c|}
\hline Month & Slope & Y-intercept & $\mathrm{n}$ & r & $F$ \\
\hline \multicolumn{6}{|c|}{$\log N v s \log W$} \\
\hline Apr & 0.947 & 1.689 & 40 & 0.864 & $114.92^{\circ}$ \\
\hline Jul & 1.060 & 1.948 & 38 & 0.837 & $82.72 \cdots$ \\
\hline \multicolumn{6}{|c|}{$\log S v s \log W$} \\
\hline Apr & 0.440 & 0.885 & 40 & 0.735 & $47.74^{\cdots}$ \\
\hline Jul & 0.471 & 0.924 & 38 & 0.647 & $102.91^{\cdots}$ \\
\hline \multicolumn{6}{|c|}{$\log S$ vs $\log N$} \\
\hline Apr & 0.423 & 0.157 & 40 & 0.825 & $81.03^{\cdots}$ \\
\hline Jul & 0.380 & 0.141 & 38 & 0.812 & $66.04 \cdots$ \\
\hline
\end{tabular}




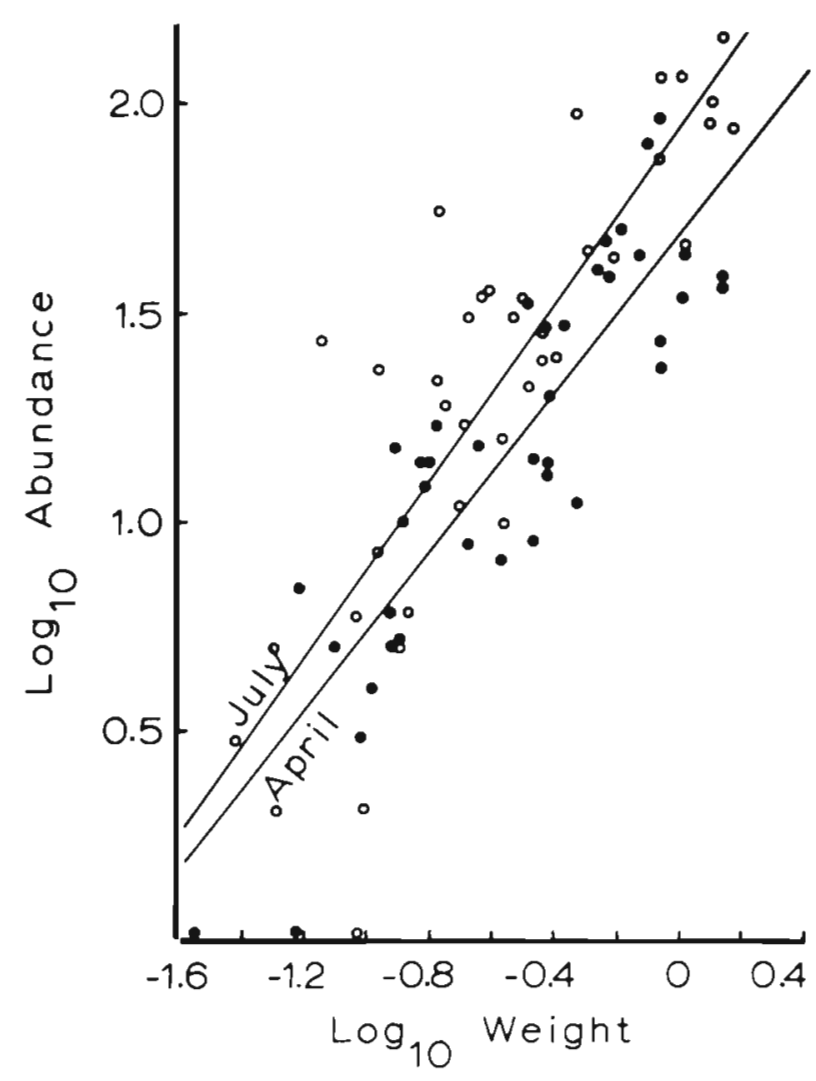

Fig. 1. Abundance of macrofauna on the capitula of Penicillus capitatus as a function of alga weight. Closed circles = April collections; open circles = July. Least squares regression lines shown

cantly higher numbers of individuals than April collections (Table 2).

Species richness was significantly correlated with both Penicillus capitatus weight and abundance of individuals when the data were $\log _{10}$-transformed (Fig. $2 \& 3$, Table 1). Animal abundance was the best predictor of species richness, explaining $68 \%$ of the variation in April, and $66 \%$ in July. Multiple linear regression models, using both numbers of individuals and $P$. capitatus weight as independent variables,

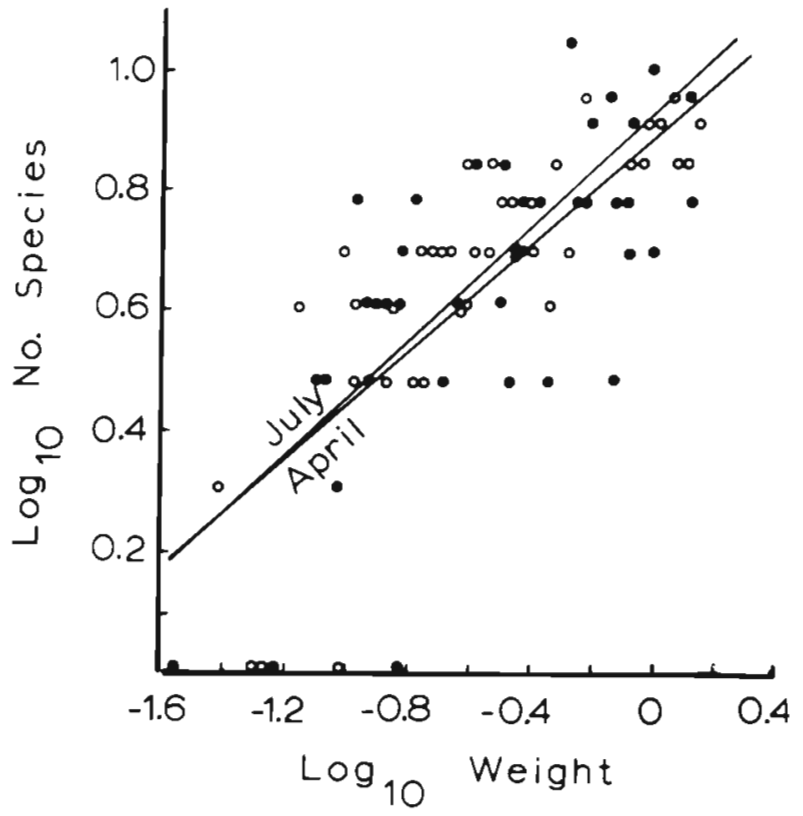

Fig. 2. Species richness of macrofauna on the capitula of Penicillus capitatus as a function of alga weight. Closed circles $=$ April collections; open circles $=$ July. Least squares regression lines shown

improved the correlation coefficients to 0.911 and 0.915 for April and July collections, respectively. Consequently, approximately $82 \%$ of the variation in species richness is explained by the 2 predictors examined. Analysis of covariance revealed no significant seasonal effects on species richness with $P$. capitatus weight $(p>0.10)$ and a weak seasonal effect with faunal abundance $(p<0.10)$ (Table 2).

For comparative purposes, abundance of macrofauna may be expressed in terms of numbers of individuals per unit dry weight and per unit surface area of different macrophytes. Penicillus capitatus has $634 \mathrm{~cm}^{2} \mathrm{~g}^{-1}$ ash-free dry wt (Lewis unpubl.), (or $199 \mathrm{~cm}^{2} \mathrm{~g}^{-1}$ dry wt) and Halodule wrightii has $715 \mathrm{~cm}^{2} \mathrm{~g}^{-1} \mathrm{dry}$ wt (Stoner 1980). Despite considerable variation in the abundance of fauna in samples of $P$. capitatus and $H$.

Table 2. Penicillus capitatus. Results of analyses of covariance for seasonal effects on abundance and species richness of macrofauna on capitula

\begin{tabular}{|c|c|c|c|c|c|}
\hline \multirow[b]{2}{*}{ Y-variable } & \multirow[b]{2}{*}{ Covariate } & \multirow[b]{2}{*}{ Factor } & \multirow[b]{2}{*}{$\mathrm{n}$} & \multicolumn{2}{|c|}{$\begin{array}{c}\text { F values } \\
\text { Test for differences among }\end{array}$} \\
\hline & & & & Slopes & Intercepts \\
\hline Abundance & P. capitatus weight & Season & 78 & $0.553_{(1,74)}$ & $10.622 \cdots{ }_{(1,75)}$ \\
\hline Species richness & P. capitatus weight & Season & 78 & $0.487_{(1,74)}$ & $0.396_{(1,75)}$ \\
\hline Species & Abundance & Season & 78 & $1.248_{(1,74)}$ & $3.782^{+}(1,75)$ \\
\hline \multicolumn{6}{|c|}{ Significance: ${ }^{+} p<0.10 ; \cdots p<0.005$} \\
\hline
\end{tabular}


Fig. 3. Species richness of macrofauna on the capitula of Penicillus capitatus as a function of animal abundance. Closed circles $=$ April collections; open circles $=$ July. Least squares regression lines shown

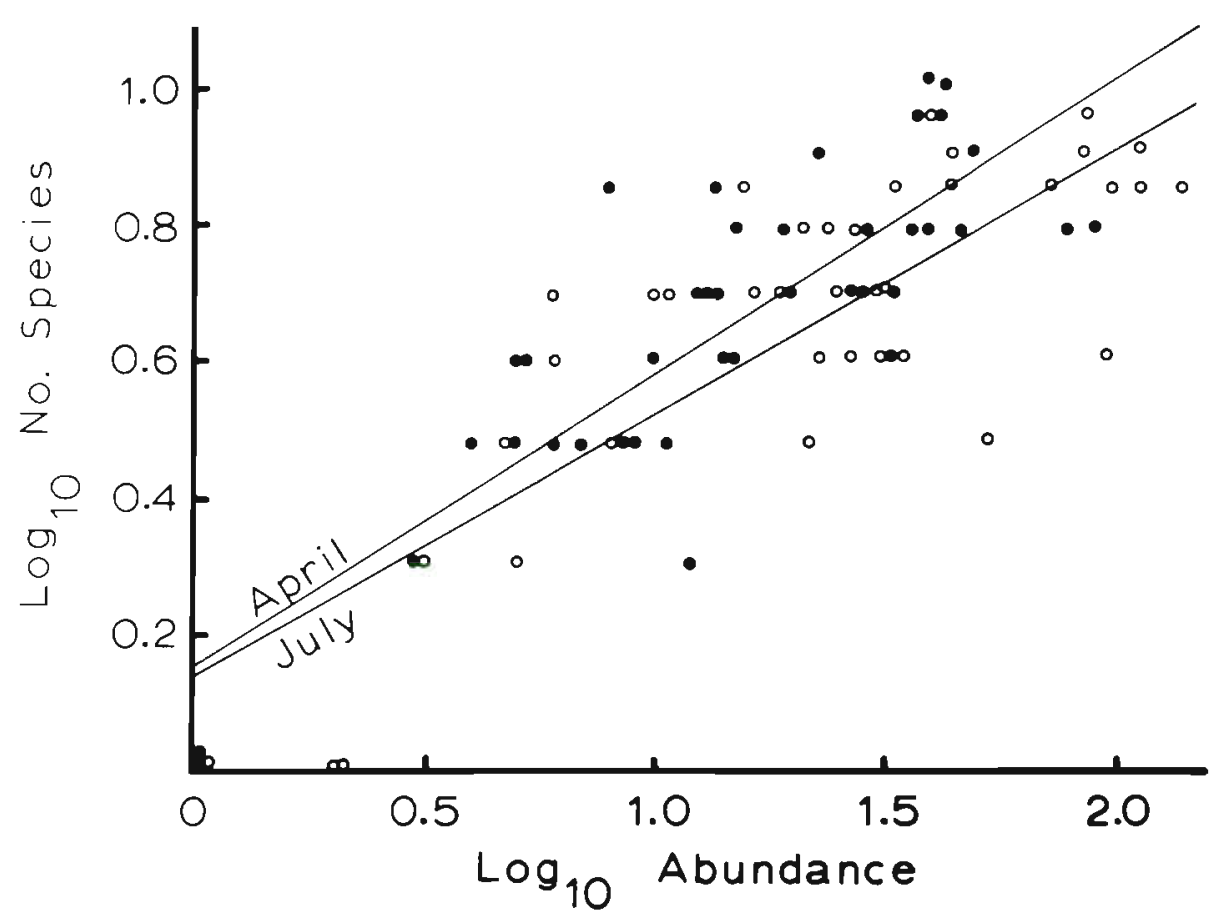

Table 3. Abundance of macrofauna on Halodule wrightii and Penicillus capitatus standardized to numbers per unit macrophyte dry weight and surface area. Values are means $\pm \mathrm{SD}$

\begin{tabular}{|c|c|c|c|}
\hline \multirow[b]{2}{*}{ Month } & \multirow{2}{*}{$\begin{array}{c}\text { Halodule } \\
\text { wrightii }\end{array}$} & \multicolumn{2}{|c|}{ Penicillus capitatus } \\
\hline & & Seagrass site & Reef site \\
\hline \multicolumn{4}{|c|}{ No. $g^{-1}$ dry wt } \\
\hline Apr & $12.0 \pm 4.4$ & $59.4 \pm 30.0$ & - \\
\hline Jul & $15.2 \pm 13.4$ & $102.4 \pm 76.7$ & $181.6 \pm 95.4$ \\
\hline \multicolumn{4}{|c|}{ No. $100 \mathrm{~cm}^{-2}$} \\
\hline Apr & $1.67 \pm 0.61$ & $29.1 \pm 15.8$ & - \\
\hline Jul & $2.13 \pm 1.88$ & $51.4 \pm 38.6$ & $91.3 \pm 47.9$ \\
\hline
\end{tabular}

wrightii the capitula of $P$. capitatus represent islands of very high animal density compared to the surrounding $H$. wrightii habitat, regardless of the standardization used (Table 3). The concentration of macrofauna on $P$. capitatus tops is even more pronounced in the reef habitat where few alternative microhabitats exist.

The macrofauna of Penicillus capitatus was dominated numerically by members of the tanaidacean genus Leptochelia (Table 4). Two species were collected in approximately equal numbers, L. dubia and $L$. forresti. Other abundant fauna were the isopod Bagatus stylodactylus, 2 undescribed amphipods in the genus Maera, and a large, unidentified harpacticoid copepod. Species composition varied little with $P$. capitatus size (Fig. 4), except that Leptochelia species decreased in relative abundance with increasing $P$. capitatus weight in July, while $B$. stylodactylus increased in abundance. Again, numbers of species collected were largely a function of faunal abundance and did not increase with alga size when abundance was similar within the different $P$. capitatus size classes. Because of considerable variation in lengths, $L$. forresti, L. dubia, Maera sp. A, Maera sp. C, and B. stylodactylus showed no significant change in size with $P$. capitatus size class (ANOVA, $\mathrm{p}>0.10$ ).

Penicillus capitatus differed distinctively from Halodule wrightii in species composition and relative abundances (Table 4). Although Leptochelia species dominated the fauna on both macrophytes, only 1 Maera individual was collected on $H$. wrightii, and isopods were relatively rare on the seagrass. Cumaceans and the large harpacticoid were found only on $P$. capitatus. On the other hand, the amphipod Melita sp. and shrimp were found only on $H$. wrightii, and the amphipods Cymadusa filosa and Lembos unicornis were of greatest relative abundance on $H$. wrightii. Cluster analysis (Fig. 5) indicated that the fauna of $P$. capitatus collected in reef and seagrass habitats were very similar, but were dissimilar to those associated with $H$. wrightii. Seasonal effects on species composition appeared to be greater in the $H$. wrightii fauna than that associated with $P$. capitatus.

On the basis of numbers of species collected, PenicilIus capitatus collected in April appeared to support the most diverse assemblage of crustaceans (Table 4); however, the relation was largely a function of the number of individuals collected. When the rarefaction method of Heck et al. (1975) and Simberloff (1978) was used to compensate for numbers of individuals in the 
Table 4. Composition of macrofauna associated with the seagrass Halodule wrightii and Penicillus capitatus in 2 different locations. Numbers of individuals collected and percent of total collection (in parentheses)

\begin{tabular}{|c|c|c|c|c|c|}
\hline \multirow[t]{2}{*}{ Species taxa } & \multicolumn{2}{|l|}{ April } & \multicolumn{3}{|c|}{ July } \\
\hline & $\begin{array}{c}\text { Seagrass-associated } \\
\text { Penicillus }\end{array}$ & Halodule & $\begin{array}{c}\text { Seagrass-associated } \\
\text { Penicillus }\end{array}$ & $\begin{array}{c}\text { Reef-associated } \\
\text { Penicillus }\end{array}$ & Halodule \\
\hline \multicolumn{6}{|l|}{ TANAIDACEA } \\
\hline Leptochelia dubia & $201(22.6)$ & $18(17.3)$ & $313(21.5)$ & $235(19.7)$ & $28(28.3)$ \\
\hline Leptochelia forresti & $226(25.4)$ & $15(14.4)$ & $401(27.6)$ & $256(21.4)$ & $12(12.1)$ \\
\hline \multicolumn{6}{|l|}{ AMPHIPODA } \\
\hline Cymadusa filosa & $8 \quad(0.9)$ & $13(12.5)$ & & & $31(31.3)$ \\
\hline Elasmopus pocillimanus & $3(0.3)$ & & $8 \quad(0.5)$ & $9 \quad(0.7)$ & \\
\hline Ericthonius brasiliensis & & & & $29(2.4)$ & \\
\hline Hemiaegina minuta & $1(0.1)$ & & & & \\
\hline Hyale periperi & & & & $19(1.6)$ & \\
\hline Lembos unicornis & $1 \quad(0.1)$ & $10 \quad(9.6)$ & 21 (1.4) & $4 \quad(0.3)$ & $22(22.3)$ \\
\hline Leucothoe spinicarpa & & $7(6.7)$ & & & \\
\hline Maera sp. A & $114(12.8)$ & & $53 \quad(3.7)$ & $146(12.2)$ & \\
\hline Maera sp. C & $160(18.0)$ & $1(1.0)$ & $28 \quad(1.9)$ & $22(19.1)$ & \\
\hline Melita sp. A & & $3(2.9)$ & & & $2 \quad(2.0)$ \\
\hline Pontogeneia bartchi & $2 \quad(0.2)$ & $11(10.6)$ & & & \\
\hline Unident. amphipod & $3 \quad(0.3)$ & & & & \\
\hline \multicolumn{6}{|l|}{ ISOPODA } \\
\hline Bagatus stylodactylus & $105(11.8)$ & $9 \quad(8.7)$ & $416(28.6)$ & $191(16.0)$ & \\
\hline Cirolana parva & $2(0.2)$ & & $7(0.5)$ & $1(0.1)$ & \\
\hline Gnathia puertoricensis & & & $1 \quad(0.1)$ & $1(0.1)$ & \\
\hline Mesanthura decorata & & & & $1 \quad(0.1)$ & \\
\hline Paracerceis caudata & $3(0.3)$ & & & 21 & \\
\hline \multicolumn{6}{|l|}{ DECAPODA } \\
\hline Alpheus sp. & & $7 \quad(6.7)$ & & & $1(1.0)$ \\
\hline Majidae & $1 \quad(0.1)$ & & & & \\
\hline Paguridae & $5 \quad(0.6)$ & $1(1.0)$ & $4 \quad(0.3)$ & & \\
\hline Palaemonetes sp. & & $2(1.9)$ & & & \\
\hline Periclimenes sp. & & $4 \quad(3.8)$ & & & $1 \quad(1.0)$ \\
\hline Xanthidae & $1(0.1)$ & $3 \quad(2.9)$ & & & $2(2.0)$ \\
\hline Unident. crab juvenile & & & $1(0.1)$ & & \\
\hline \multicolumn{6}{|l|}{ MISCELLANEOUS } \\
\hline Cumacea & $2 \quad(0.2)$ & & $5 \quad(0.3)$ & $8 \quad(0.7)$ & \\
\hline Harpacticoida & $51 \quad(5.7)$ & & $197(13.5)$ & $47 \quad(3.9)$ & \\
\hline Pycnogonida & $2 \quad(0.2)$ & & & & \\
\hline TOTAL N & 891 & 104 & 1455 & 1196 & 99 \\
\hline TOTAL S & 19 & 14 & 13 & 15 & 8 \\
\hline E.N.S. $(100)$ & 9.1 & 12.8 & 8.1 & 10.1 & 7.0 \\
\hline
\end{tabular}

sample, values for expected numbers of species drawn with sample sizes of 100 individuals (E.N.S.100) were similar. Highest expected number of species was found on Halodule wrightii in April (12.8) and lowest E.N.S. was associated with $H$. wrightii in July (7.0). E.N.S. values for $P$. capitatus all ranged between 8.1 and 10.1 , once again indicating that species richness was a function of numbers of individuals, not alga size.

To test for potential interspecific interactions among animals living on the capitula of Penicillus capitatus, Hurlbert's (1969) coefficient of interspecific association $\left(\mathrm{C}_{8}\right)$ was calculated for all pairwise combinations of the 5 most abundant taxa from the seagrass site (Table 5).
Positive values indicate that 2 species tend to co-occur. Most of the associations did not vary significantly from zero indicating no interactions; none of the associations were negative. Significant positive relations occurred between the 2 Maera species during both collections and between Leptochelia forresti and $L$. dubia in July.

\section{Recolonization experiment}

In less than $1.5 \mathrm{~h}, 6$ crustacean species colonized defaunated Penicillus capitatus (Fig. 6), and species 


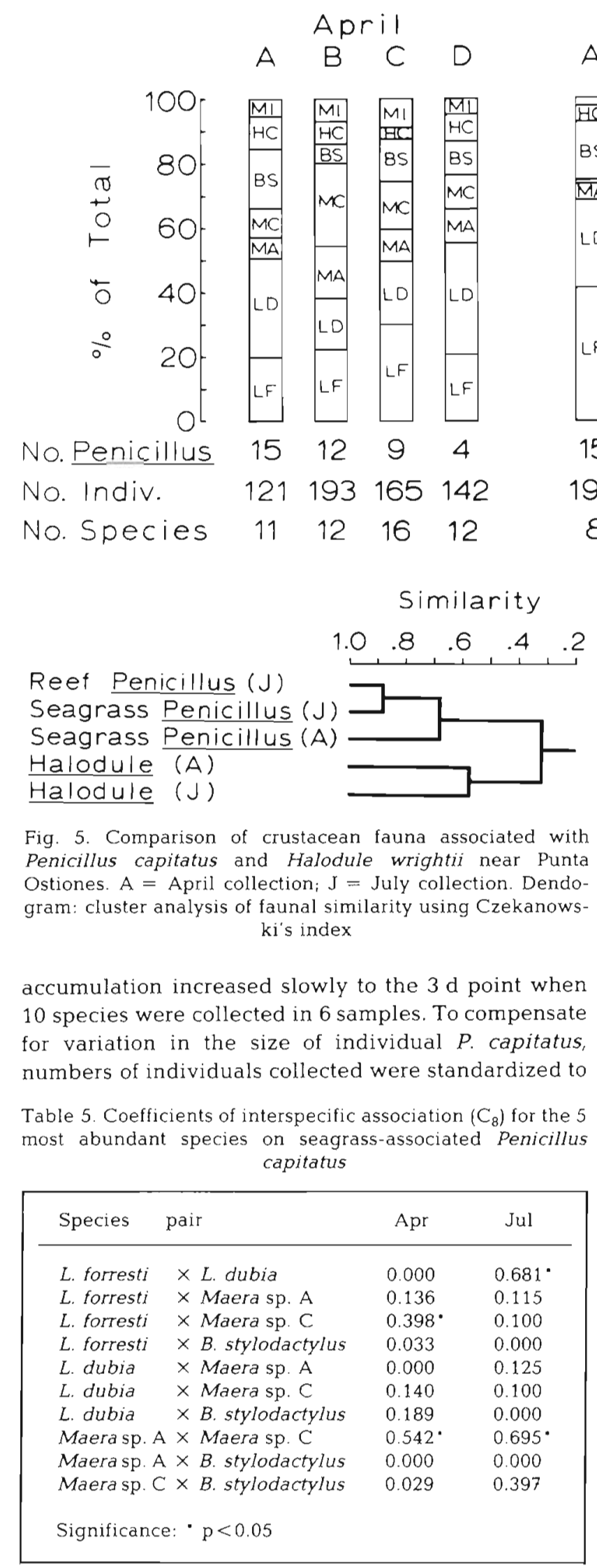

A $\quad$ B $\quad$ C

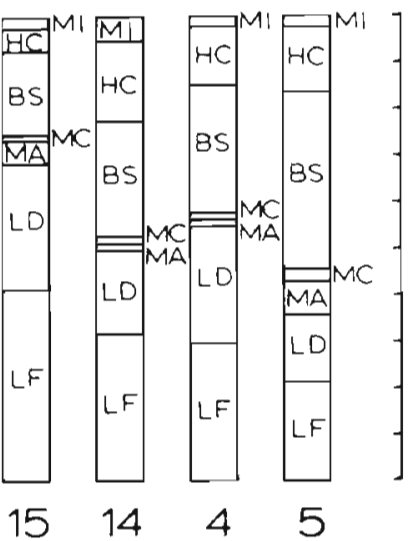

Fig. 4. Relative abundance of the most numerous taxa on Penicillus capitatus by alga size class. $\mathrm{A}=<0.2 \mathrm{~g}$ dry wt, $\mathrm{B}=0.2$ to $0.5 \mathrm{~g}, \mathrm{C}=0.5$ to $1.0 \mathrm{~g}, \mathrm{D}=>1.0 \mathrm{~g}$. LF Leptochelia forresti; LD Leptochelia dubia; MA Maera sp. A; MC Maera sp. C; BS Bagatus stylodactylus; HC harpacticoid copepod; MI miscellaneous other taxa 
Fig. 7. Relative abundance of the most numerous taxa colonizing defaunated Penicillus capitatus as a function of time. Species codes same as in Fig. 4
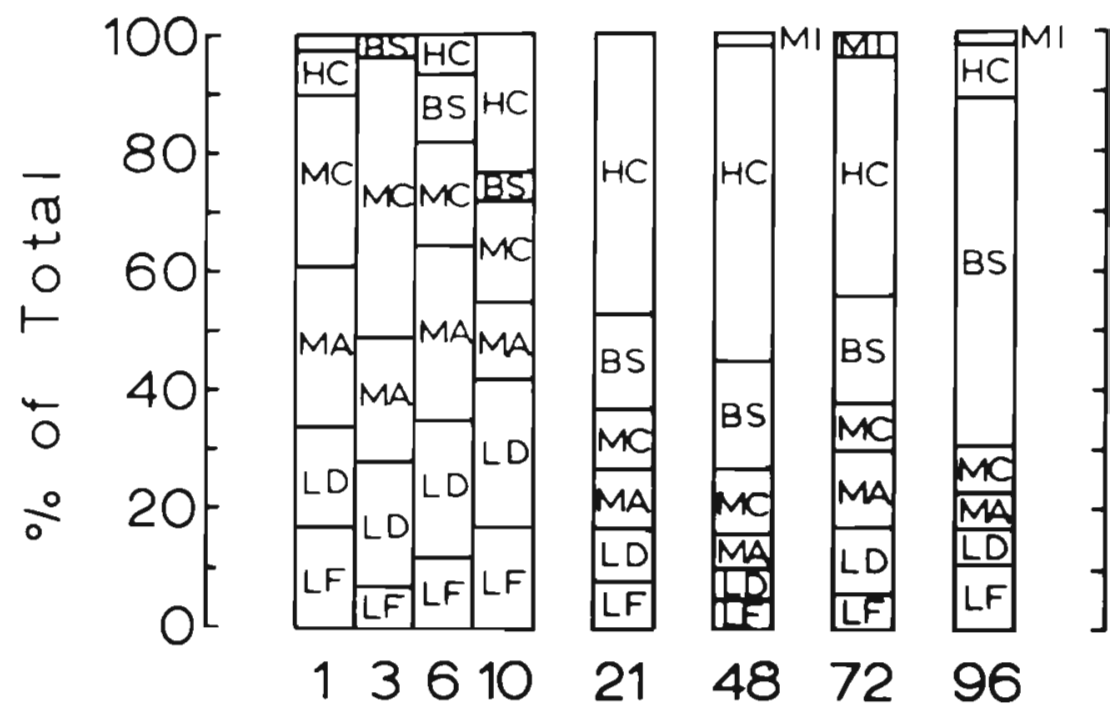

Hours $\left(58 \mathrm{~g}^{-1}\right.$ dry $\left.\mathrm{wt}\right)$ was similar to the abundance on unmanipulated P. capitatus (59.4 $\mathrm{g}^{-1}$ dry wt) (Table 3) and species richness for the 55 individuals collected (E.N.S. ${ }_{100}=8$ ) was compatible with the E.N.S. ${ }_{(100)}$ of 9.1 for unmanipulated $P$. capitatus assemblages.

Patterns of colonization by individual species (Fig. 7) showed that Maera and Leptochelia species colonized Penicillus capitatus very quickly in the daytime. By evening of the first day, harpacticoid copepods appeared along with the isopod Bagatus stylodactylus. At $24 \mathrm{~h}$, the large harpacticoid had become the most abundant species; the rapid overnight increase in harpacticoids indicates nocturnal locomotory activity. After the first 24 h, Leptochelia and Maera populations remained relatively stable, but by Day $4, B$. stylodactylus became the numerically dominant species.

Mean lengths of the 5 most abundant peracarid crustaceans collected on the manipulated Penicillus capitatus showed no significant variation over time indicating that colonization was not related to animal size.

\section{DISCUSSION}

The relation between numbers of species and island size has been of interest to biologists since first examined by Preston $(1960,1962)$ and Williams (1964). MacArthur \& Wilson (1967) provided the theoretical framework upon which a multitude of species-area studies have followed in aquatic as well as terrestrial habitats (see review by Connor \& McCoy 1978). In some cases, particularly in studies of terrestrial fauna on islands, increasing species richness with island size may be a function of increasing numbers of habitat types; however, recent studies in the marine field using smaller 'islands' such as macroalgae (Gunnill 1982b, 1983, Lewis 1982, Stoner \& Greening 1984) and individual coral heads (Gotelli \& Abele 1982), have indicated the significance of abundance of individuals as a proximate variable affecting species richness. Similarly, in this study, species-area effects on the tops of Penicillus capitatus were best explained by animal abundance patterns. Given the essentially identical structure of large and small $P$. capitatus, increasing species richness is independent of habitat heterogeneity and probably results from a simple random sampling effect.

Variation in the species composition of Penicillusassociated crustaceans may be related to chance events. Like the lottery system proposed by Sale (1978) for reef fishes, priority of arrival as recruits may determine which species hold space on the alga. Lack of negative interactions among even the congeneric species pairs suggest that a hierarchy of interspecific competition on $P$. capitatus is unlikely. However, changes in species composition over time on defaunated $P$. capitatus and reduced numbers of species with high animal densities in July suggest some non-random effects, such as (1) differential immigration and/or emigration rates; (2) displacement of certain taxa such as harpacticoid copepods; (3) certain positive associations such as those between the 2 Maera species and the 2 Leptochelia species; (4) differential susceptibility to predation.

First, the largest change in faunal composition occurred during the first night of the recolonization experiment suggesting that certain of the key species were nocturnal immigrants. Nocturnal locomotory 
activity is well-known in seagrass-associated peracarids (Robertson \& Howard 1978, Stoner 1980) and any differential dispersal characteristics could greatly influence the pattern of recruitment on Penicillus capitatus. Second, Nagle (1968) suggested that competitive interactions among peracarid species result in displacement of certain species from macroalgae. Replacement of harpacticoid copepods by the isopod Bagatus stylodactylus indicates that such interactions could take place on $P$. capitatus. Manipulative experiments would be most useful in testing for displacement. Third, positive associations and simultaneous recruitment patterns are most likely related to similar habitat or food requirements coupled with similar locomotory characteristics. Many peracarid species have similar food habits (Zimmerman et al. 1979) and requirements for shelter.

Large differences between crustacean assemblages associated with Penicillus capitatus and with Halodule wrightii are probably related to differential susceptibility to predation and associated habitat choices. Juvenile fishes, many of which consume large numbers of peracarids, are very abundant in seagrass beds (Adams 1976, Heck \& Orth 1980, Stoner 1983, Livingston 1984). At the study site, these inclucled small grunts, snappers, damselfishes, and mojarras. There seems little doubt that the extreme density of crustaceans on $P$. capitatus tops is a function of the protection offered to small crustaceans by the densely packed filaments of the alga and fine silt available for tubebuilding. Comparatively, the sparse blades of $H$. wrightii offer little refuge to peracarids. The islands of refuge would be particularly important in the backreef area where few other similar substrata occur; densities on $P$. capitatus were greatest in that area. Similar to the findings of this study, Lewis (1982, unpubl.), in the Gulf of Mexico, showed that surrounding seagrasses supported relatively few crustaceans compared to a variety of macroalgae including Penicillus lamourouxii.

Large differences in species composition between Penicillus capitatus and Halodule wrightii associates may also be a result of habitat choice. The larger crustaceans such as shrimps and crabs, absent from $P$. capitatus, undoubtedly receive little protection from predation on the alga and select alternative habitats. Although some peracarid species, such as the 2 Leptochelia species, were found in all habitats, many species appear to be habitat specialists. Elasmopus pocillimanus, Erichthonius brasiliensis, Hyale periperi, Maera sp. A, Maera sp. C (except 1 individual), Cirolana parva, Paracerceis caudata, cumaceans and the large harpacticoid copepod were all abundant and collected exclusively on $P$. capitatus. Leucothoe spinicarpa and Melita sp. A were collected only on $H$. wrightii. Given the similar sizes and general behavioral characteristics of the taxa it would seem likely that habitat associations are a function of habitat choice, perhaps ultimately related to the effects of predation.

The present study shows that species-area effects may be an artifact of the number of individuals inhabiting an island habitat. Early colonization is probably stochastic, with the best dispersers arriving first. Colonization patterns, however, suggest that the effects of density-dependent phenomena increase with time, and that the species are not distributed independently. Penicillus species, because of their abundance in shallow-water habitats, their unique morphology, and small, island-like characteristics, provide an unusual model system for new experimental research on congeneric use of space, and patterns of immigration, emigration, and species richness.

Acknowledgements. This research was supported by a grant from the Center for Energy and Environment Research, University of Puerto Rico. I am particularly grateful to Zulma Raquel Marrero for her help in the collections and for completing most of the microscope work. Beverly Yoshioka kindly assisted in the recolonization experiment. Dr. Jurgen Sieg confirmed our identifications of the tanaidaceans. The manuscript was prepared by Terry Robles and thoughtfully reviewed by Graham Lewis and Gary Owen

\section{LITERATURE CITED}

Abele, L. G. (1984). Biogeography, colonization and experimental structure of coral-associated crustaceans. In Strong, D. R., Simberloff, D. S., Abele, L. G., Thistle, A. B. (ed.) Ecological communities: conceptual issues and the evidence. Princeton Univ. Press, Princeton, N. J., p. 123-137

Abele, L. G., Patton, W. K. (1976). The size of coral heads and the community biology of associated decapod crustaceans. J. Biogeogr. 3: 35-47

Adams, S. M. (1976). The ecology of eelgrass, Zostera marina (L.), fish communities. I. Structural analysis. J. exp. mar. Biol. Ecol. 22: 269-291

Connor, E. F., MCCoy, E. D. (1978). The statistics and biology of the species-area relationship. Am. Nat. 113: 791-833

Friedman, E. I., Roth, W. C. (1977). Development of the siphonous green alga Penicillus and the Espera state. J. Linn. Soc. 74: 189-214

Gotelli, N. J., Abele, L. G. (1982). Community patterns of coral-associated decapods. Mar. Ecol. Prog. Ser 13: $131-139$

Gunnill, F. C. (1982a). Macroalgae as habitat patch islands for Sentillidium lamellipes (Copepoda: Harpacticoida) and Ampithoe tea (Amphipoda: Gammaridae). Mar. Biol. 69: 106-116

Gunnill, F. C. (1982b). Effects of plant size and distribution on the numbers of invertebrate species and individuals inhabiting the brown alga Pelvetia fastigiata. Mar Biol. 69: $263-280$

Gunnill, F. C. (1983). Seasonal variations in the invertebrate faunas of Pelvetia fastigiata (Fucaceae): Effects of plant size and distribution. Mar Biol. 73: 115-130 
Heck, K. L., Jr., Orth, R. J. (1980). Seagrass habitats: the roles of habitat complexity, competition and predation in structuring associated fish and motile macroinvertebrate assemblages. In: Kennedy, V S. (ed.) Estuarine perspectives. Academic Press, New York, p. 449-464

Heck, K. L., Belle, G. van, Simberloff, D. S. (1975). Explicit calculation on the rarefaction diversity measurement and the determination of sufficient sample size. Ecology 56: 1159-2261

Hurlbert, S. H. (1969). A coefficient of interspecific association. Ecology 50: 1-9

Lewis, F. G., III. (1982). Habitat complexity in a subtropical seagrass meadow: the effects of macrophytes on species composition and abundance in benthic crustacean assemblages. Ph. D. Dissertation, Florida State Univ., Tallahassee

Livingston, R. J. (1984). Trophic response of fishes to habitat variability in coastal seagrass systems. Ecology 65: $1258-1275$

MacArthur, R. H., Wilson, E. O. (1967). The theory of island biogeography. Princeton Univ. Press., Princeton, N. J.

Nagle, J. S. (1968). Distribution of the epibiota of macrobenthic plants. Publs. Inst. mar. Sci. Univ. Tex. 13: 105-144

Preston, F. W. (1960). Time and space and the variation of species. Ecology $41: 611-627$

Preston, F. W. (1962). The canonical distribution of commonness and rarity. Ecology 43: 185-215, 410-432

Robertson, A. I., Howard, R. K. (1978). Diel trophic interactions between vertically-migrating zooplankton and their fish predators in an eelgrass community. Mar. Biol. 48 $207-213$

Sale, P. F. (1978). Coexistence of coral reef fishes - a lottery for living space. Environ. Biol. Fish. 3: 85-102

Simberloff, D. (1978). Use of rarefaction and related methods in ecology. In: Dickson, K. L., Cairns, J., Jr., Livingston, R. J. (ed.) Biological data in water pollution assessments: quantitative and statistical analyses. American Society for Testing Materials, ASTM STP 652, p. 150-165

Stoner, A. W. (1980). Perception and choice of substratum by epifaunal amphipods associated with seagrasses. Mar. Ecol. Prog. Ser. 3: 105-111

Stoner, A. W (1983). Distribution of fishes in seagrass meadows: role of macrophyte biomass and species composition. Fish. Bull. U. S. 81: 837-846

Stoner, A. W., Greening, H. S. (1984). Geographic variation in the macrofaunal associates of pelagic Sargassum and some biogeographic implications. Mar. Ecol. Prog. Ser. 20: 185-192

Taylor, W. R. (1960). Marine algae of the eastern tropical and subtropical coasts of the Americas. Univ. Michigan Press, Ann Arbor

Williams, C. B. (1964). Patterns of the balance of nature and related problems in quantitative ecology. Academic Press, New York

Zimmerman, R. J., Gibson, R., Harrington, J. (1979). Herbivory and detrivory among gammaridean amphipods from a Florida seagrass community. Mar. Biol. 54: 41-47

This paper was submitted to the editor; it was accepted for printing on July 27, 1985 